Saad Awad Abdelrahman, Performance and exhaust emission characteristics of a diesel engine using alternative fuels, pp. 2140 - 2159

\title{
PERFORMANCE AND EXHAUST EMISSION CHARACTERISTICS OF A DIESEL ENGINE USING ALTERNATIVE FUELS
}

\author{
Saad Awad Abdelrahman \\ Mech. Science, Eng., Dept., The specialized studies Academy, Ministry of higher education \\ Email: saadawad336@yahoo.com
}

Received 12 June 2013; accepted 30 June 2013

\begin{abstract}
The present work introduces an improvement performance and reduces the exhaust emissions of Diesel engine. The experimental comparative study of the combustion characteristics and exhaust emissions for a single cylinder Diesel engine using LPG-Diesel and CNG-Diesel dual fuels separately are studied. Different ratios of LPG and CNG in Diesel fuel up to $70 \%$ were used respectively. The test rig was furnished with a computer-controlled data acquisition system and the necessary measuring instruments to measure and record ignition delay, combustion duration, peak cylinder pressure, dual specific fuel consumption and exhaust emissions. The engine was tested at different speeds and loads. The results indicated that the ignition delay of both LPG-Diesel and CNG-Diesel dual fuel are obviously longer than that of Diesel fuel only. The combustion duration for the two cases is slightly reduced with the increase of gaseous fuel ratio at low speeds; however, it increases at high speeds. As gaseous fuel ratio is increased, the peak cylinder pressure is slightly reduced at low loads, however, at high loads; the peak cylinder pressure strongly decreases. The level of $\mathrm{NO}_{\mathrm{x}}$ emissions under dual fuel operation is lower than normal Diesel operation at different gaseous fuel ratios. $\mathrm{CO}$ and $\mathrm{HC}$ emissions for the two cases decrease with the increase of gaseous fuel ratio. The dual specific fuel consumption slightly increases with the increase of gaseous fuel ratio. The final results showed that when using CNG dual fuel, the combustion performance increases while the exhaust emissions decrease compared with Diesel and LPG dual fuel.
\end{abstract}

Keywords: LPG; CNG; Dual fuel combustion, Diesel engine; Performance, Exhaust emissions;

\section{Introduction}

In recent years, the high cost of liquid fuel that was derived from crude oil and the growing concern of environmental pollution have lead to increase the search for alternative fuels. Gaseous fuel in general is promising alternative fuel due to its economical costs, high octane number, and high calorific value and lower polluting exhaust emissions [1-4]. The foundations of alternative fuels for internal combustion engines were initiated based on dual fuel concept. There are many published works on the use of gaseous fuels in dual fuel engines [5-9]. In dual fuel engines, gaseous fuel is inducted with the intake air through the intake manifold and is compressed like in a conventional Diesel engine. A small amount of Diesel fuel is injected near the end of the compression stroke to ignite the gaseous-air mixture. The gaseous fuel in the present study is the liquefied petroleum gas (LPG) and compressed natural gas (CNG). Liquefied petroleum gas (LPG) has been studied from the point of view of performance and exhaust emissions [10-13]. At low load, when the LPG concentration is low in dual fuel engines, the ignition delay of the pilot diesel fuel increases and some of the homogeneously dispersed LPG remains unburned [10\&11]. Poor combustion of LPG under low loads is due to a dilute LPG-air mixture and

Journal of Engineering Sciences, Assiut University, Faculty of Engineering, Vol. 41, No. 6, November, 2013, E-mail address: jes@aun.edu.eg 
Saad Awad Abdelrahman, Performance and exhaust emission characteristics of a diesel engine using alternative fuels, pp. 2140 - 2159

resulting of high $\mathrm{CO}$ and unburned HC emissions [12]. However, at high loads increased admission of LPG can result in uncontrolled reaction rates near the pilot fuel spray and leads to knock $[11,13]$. CNG is basically composed of methane whereas LPG is a mixture of propane, butane and other chemicals, [14]. Another important difference from a physical point of view is that $\mathrm{CNG}$ does not liquefy under high pressure, but it remains a gas, unless it is cooled down to at least $-164^{\circ} \mathrm{C}$ [15]. LPG becomes liquid when it is compressed or when it is cooled down (therefore its name is Liquefied Petroleum Gas). CNG comes directly from a gas field. The only process, which sometimes needs to be done, is the filtering of the gas. But usually, the gas can be used as a fuel right away after the compression process. CNG has a density less than the air, while LPG has twice density of the air. Compressed natural gas $(\mathrm{CNG})$ used in dual fuel engines has been studied from point of view of the combustion duration and ignition delay [16-19]. A CNG-Diesel dual fuel engine offers an attractive alternative to both Diesel and spark ignition engines. Also, CNG readily forms homogenous air/fuel mixtures which can be ignited and burned over a wide flammability range [20\&21]. This pre-mixed combustion produces lower nitrogen oxides (NOx) emissions and soot emissions compared to Diesel engines. At low engine loads, lower fuel combustion efficiency has been observed [22], which results in significant amounts of hydrocarbon $(\mathrm{HC})$ and carbon monoxide $(\mathrm{CO})$ in the exhaust emissions. Using dual fuel engine, Elnajjar et al,[23],have investigated the effects of different engine parameters and their correlation to the overall generated noise. The study was conducted for three different fuels: pure diesel fuel, natural gas and duel fuel of dieselLPG. The study reported the location (crank angle) corresponding to maximum cylinder pressure and maximum pressure rise rate. Vezir Ayhan et at [24] investigated the effects of LPG injection during air inlet period on performance characteristics and emissions. The engine has been modified to determine the best LPG substitution for dual operation in order to improve the emissions quality while maintaining high thermal efficiency in comparison to a conventional diesel engine. LPG injection rate were selected as 5, 10, 15 and $25 \%$ on a mass basis. Minimum SFC and maximum brake efficiency obtained with 15\% LPG between 1400 and $1800 \mathrm{rpm}$ engine speeds. Optimum injection rates is found at $5 \%$ LPG in terms of exhausts emissions and performance.

In the present work, an experimental study has been conducted to create alternative dual fuel (mixture of gas and Diesel fuel) to improve the performance of diesel engine and reduce the exhaust emission. The combustion characteristics and exhaust emissions $\left(\mathrm{NO}_{\mathrm{x}}\right.$, $\mathrm{CO}$ and $\mathrm{HC}$ ) of Diesel engine using LPG-Diesel and CNG-Diesel dual fuels are experimentally compared at the same operating conditions respectively. Different ratios of LPG and CNG in diesel fuel up to $70 \%$ were used at different engine speeds and loads.

\section{Experimental Test Rig}

Schematic diagram of the present test rig and measuring devices are shown in Fig.1a and Fig.1b. The experimental work was carried out on a single cylinder Diesel engine (engine data is given in Table1). The engine is modified to work in dual fuel mode by attaching LPG or CNG supply to the intake manifold. LPG or CNG conversion kits such as the gas pressure regulator, control valve, nozzle and gauge is used. The engine was loaded by a hydraulic dynamometer for torque. The LPG or CNG flow is controlled by a control valve

Journal of Engineering Sciences, Assiut University, Faculty of Engineering, Vol. 41, No. 6, November, 2013, E-mail address: jes@aun.edu.eg 


\section{2}

Saad Awad Abdelrahman, Performance and exhaust emission characteristics of a diesel engine using alternative fuels, pp. 2140 - 2159

and entered into the gaseous fuel mixer (GFM) through a nozzle in order mix with the inlet air to the engine. The air inlet temperature is $25^{\circ} \mathrm{C}$ for all cases examined. The homogeneous mixture enters the engine combustion chamber through the engine intake valve. The mixture is ignited near top dead center by a certain amount of Diesel fuel injected. The solenoid-operated Diesel fuel injector is opened and closed by means of electric pulses from the PC computer. The flow rate $\mathbf{Q}=(\mathbf{V} / \mathbf{t})$ of diesel fuel delivered is measured by flow meter fixed on the line by opening the injector valve and the fuel pressure which supplies the fuel to the injector. The diesel fuel injector is worked first in order to know the reference voltage $\left(\mathrm{V}_{\text {ref }}\right)$ to be sent from the computer to inject the mass of diesel fuel $\left(\mathbf{m}_{\text {diesel }}\right)$. When the engine was under diesel operation only, control valve $\mathrm{V}_{1}$ was opened and $V_{2}$ was closed. When the engine was under dual fuel operation, V1, V2 and $V_{3}$ were opened (see Fig.1a and Fig.1b). Pre-calibrated temperature sensor was used to measure cylinder wall temperature $\left(\mathrm{T}_{\mathrm{W}}\right)$ at different operating conditions. A phototransistor circuit was attached to the engine crankshaft to measure its speed. The cylinder pressure was measured by a kistler piezoelectric transducer 6421A5. The crankshaft degree angle sensor and the needle valve lift sensor to define ignition delay are connected to the relevant amplifier.

A data acquisition system utilizing PCL-812PG enhanced multi-lab card was used to collect the measured data and store it in a personal computer under software control for offline analysis. The data acquisition system operates in a sequence of input channel multiplexing, signal sampling and holding, analog to digital conversion and finally storing the digital results. Another data acquisition system is using an angle encoder to collect the cylinder combustion pressure and crank angle data. The pressure signal was fed into a Kistler charge amplifier 5011B11.

The Kistler charge amplifier converts the pressure sensor output into a proportional voltage signal. The charge amplifier output is an input signal to A/D converter. The signals from the piezoelectric transducer and a crank angle sensor were fed to a two channel oscilloscope (Nicolet 4063A), sensitivity 79pc/bar. A digital oscilloscope was used to display the diagram of cylinder pressure versus crank angle, and from this diagram the ignition delay, combustion duration and maximum cylinder pressure were estimated.

A computer program was written to collect the data from the two channels at a sampling rate of 100 points per second and store the pressure and crank angle data in PC for offline analysis. A computer program in QUICK BASIC language was written to collect and find the pressure rise rate data at all cycle points from compression stroke to expansion stroke. The maximum value of pressure rise rate was recorded. Twenty pre-calibrated $K$-type thermocouples of $0.3 \mathrm{~mm}$ wire diameter, of $1 \mathrm{~mm}$ probe diameter and of $20 \mathrm{~ms}$ response time were used to measure the temperature at definite locations. A digital flue-gas analyzer computer EU-200/4 was connected to the exhaust emission of the engine by putting the probe of analyzer inside the emission tube and sealed to measure the engine exhaust emissions $\left(\mathrm{NO}_{\mathrm{x}}, \mathrm{CO}\right.$ and $\left.\mathrm{HC}\right)$. During the engine operation at constant speed and constant load, after five minutes of steady state operation, the exhaust emissions $\left(\mathrm{NO}_{\mathrm{x}}, \mathrm{CO}\right.$ and $\left.\mathrm{HC}\right)$ are read and recorded. A computer of NI-Scope software showing the pressure signal together with crankshaft angle was used. Suitable interface hardware circuits were constructed to connect between the personal computer and the sensors.

Journal of Engineering Sciences, Assiut University, Faculty of Engineering, Vol. 41, No. 6, November, 2013, E-mail address: jes@aun.edu.eg 
Saad Awad Abdelrahman, Performance and exhaust emission characteristics of a diesel engine using alternative fuels, pp. 2140 - 2159

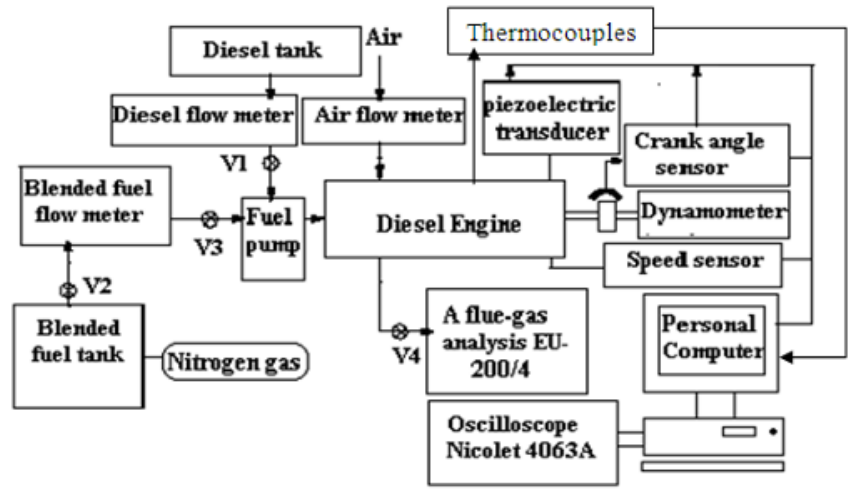

Fig. 1a. A schematic diagram of the test rig with LPG-Diesel fuel

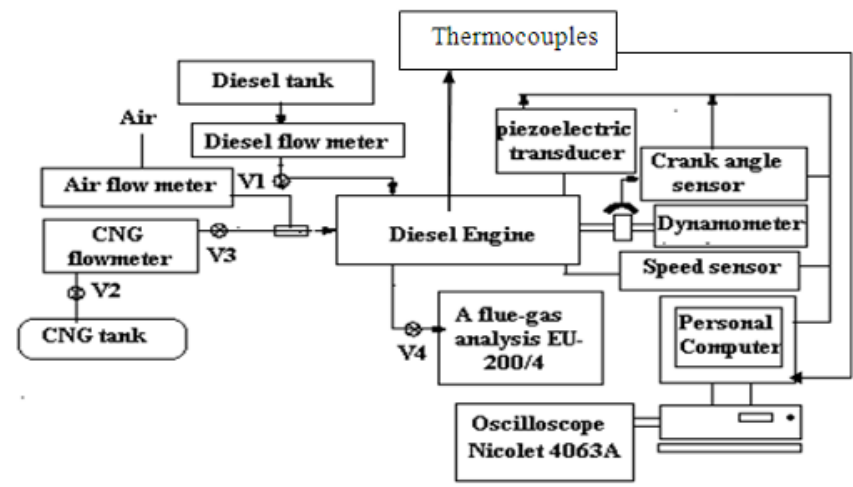

Fig. 1b. A schematic diagram of the test rig with CNG-Diesel fuel

\subsection{LPG-diesel blended fuel operation}

In this case, LPG-diesel blended fuel was prepared in the way of fuel containing dissolved gas, as shown in figure (1c). This combination was carried out in three steps. In the first step, a small amount of diesel fuel only was put in the empty LPG tank. The second step was established by a certain pressure not lower than the saturation pressure of LPG in the tank by the pressurized nitrogen gas , $\mathrm{N}_{2}$.. In the last step, a certain proportion by mass of LPG was emptied into the diesel fuel by the pressurized $\mathrm{N}_{2}$. Shaking the LPG tank by hand and immediately undertaking the experiment. The blended fuel entered the injection pump and injected into the engine cylinder by the rocking injector.

\subsection{Dual fuel (CNG-diesel) operation}

In this case, the conventional diesel-fuel engine was converted to CNG system by injecting $\mathrm{CNG}$ with the intake air and allowing the mixture to enter the engine combustion chamber through the intake valve. The mixture was ignited near top dead center by a certain amount of diesel fuel injected as shown in figure (1d). Before entering the engine cylinder, the

Journal of Engineering Sciences, Assiut University, Faculty of Engineering, Vol. 41, No. 6, November, 2013, E-mail address: jes@aun.edu.eg 
2144

Saad Awad Abdelrahman, Performance and exhaust emission characteristics of a diesel engine using alternative fuels, pp. 2140 - 2159

CNG fuel passes through a small tank (damper) to dampen the pressure fluctuations from the engine intake.

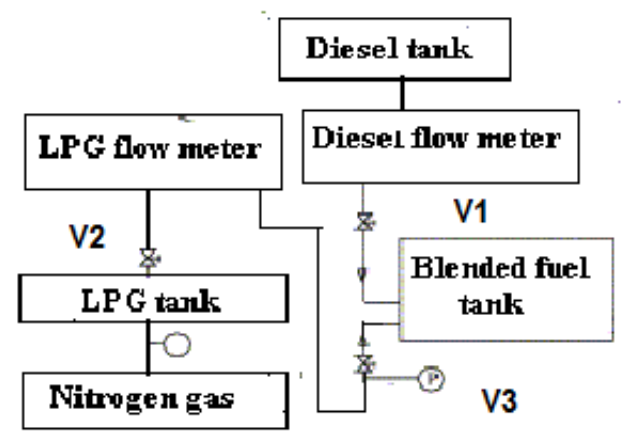

Fig. 1 c. Formation of LPG- Diesel blended fuel

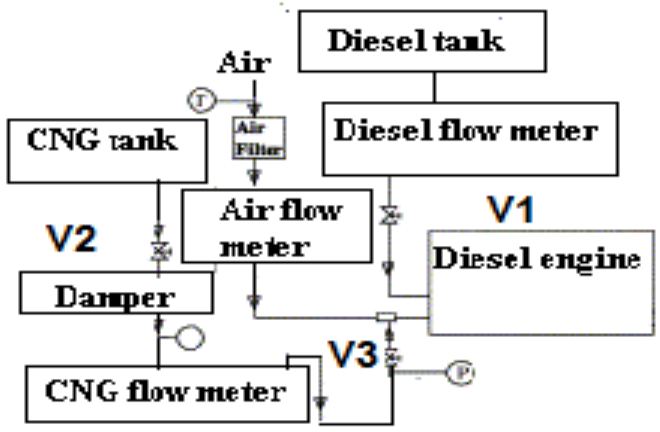

Fig. 1.d. Formation of Dual fuel (CNG- Diesel)

\section{Table 1.}

Diesel engine specification

\begin{tabular}{|l|l|}
\hline Specifications & Diesel engine \\
\hline Engine type & 4 stroke, air cooled, Single cylinder, OHV \\
\hline Model & Petter \\
\hline Rate power \& speed & $11 \mathrm{~kW}$ at $2500 \mathrm{rpm}$ \\
\hline Bore and stroke & 105 and $115 \mathrm{~mm}$ \\
\hline Compression ratio & 17 \\
\hline Displacement & $995.3 \mathrm{~cm}^{3}$ \\
\hline
\end{tabular}

\section{Test Procedure and Experimentation}

The experimental procedure was carried out according to standard automotive engine (SAE) procedures for data collection and data reduction. In the current experimental work, two sets of experiments were carried out at different experimental conditions as shown in table (2). The purpose of these experiments was to assess to the following:

Journal of Engineering Sciences, Assiut University, Faculty of Engineering, Vol. 41, No. 6, November, 2013, E-mail address: jes@aun.edu.eg 
Saad Awad Abdelrahman, Performance and exhaust emission characteristics of a diesel engine using alternative fuels, pp. 2140 - 2159

A- To study the effect of using different ratios of LPG-Diesel duel fuel on engine performance, combustion characteristics and exhaust emissions of diesel engine.

B- To study the effect of using different ratios of CNG-Diesel dual fuel on engine performance, combustion characteristics and exhaust emissions of diesel engine.

Steady state tests were carried out so that the data obtained after five minutes for each operation would enable the complete evaluation of the combustion characteristics and exhaust emissions under different engine operating conditions. The properties of fuels used during this study are presented in appendix A, [11,22].

The experimental work in this study starts by a basic engine performance, combustion characteristics and exhaust emissions using diesel fuel only at $(z=0)$. The results obtained will be used as a basis for comparison with that obtained from the other gaseous fuel addition. The test conditions are combination of these conditions listed in Table 2. Under dual fuel operation, the valves v2,v3 of LPG or CNG are opened and part of the liquid fuel is replaced by gaseous to maintain the power output of the engine as the same as for normal diesel operation at the operating conditions (loads and speeds). Also at a given engine speed and after reaching a certain power output with diesel fuel only, its flow rate and the power are kept constant by opening gaseous fuel valve until the higher value is reached. The flow rate of LPG, CNG and Diesel fuel is measured separately. In order to prevent the LPG evaporation, high pressure nitrogen was introduced into the LP G tank.

To insure high accuracy of the measured values, each reading was repeated three times and mean of the three measured values was calculated. The gas analyzer and all measuring devices were also calibrated before each measurement [25].The gas analyzer has a resolution of $0.01 \mathrm{rpm}$.

Table 2.

Experimental conditions

\begin{tabular}{|l|l|}
\hline Engine load \% of full load $(\mathrm{kW})$ & $10,25,50,75,95$ \\
\hline Engine speed (RPM) & 1500,2500 \\
\hline Gaseous fuel ratios (Z) \% & $0,10,20,30,40,50,60,70$ \\
\hline
\end{tabular}

\section{Data Reduction Equations}

The brake specific fuel consumption (BSFC) for gaseous and Diesel fuels is the rate of mass fuel consumption divided by the power produced as $(\mathrm{BSFC}=\boldsymbol{m} \cdot \boldsymbol{P}) \mathrm{kg} / \mathrm{kW}$.h. Also the gaseous fuel flow consumption is measured by the flow meter fixed on each line to the engine. When the engine is fuelled with LPG-Diesel or CNG-Diesel dual fuel, the mass ratio of LPG or CNG in the dual fuel is given by the following relation [8]:

$z=\frac{m_{\text {gas }}}{m_{\text {gas }}+m_{\text {Diesel }}} \times 100 \%$

The dual brake specific fuel consumption (DBSFC) for LPG-Diesel or CNG-Diesel is calculated according to the following equation [21]:

Journal of Engineering Sciences, Assiut University, Faculty of Engineering, Vol. 41, No. 6, November, 2013, E-mail address: jes@aun.edu.eg 
Saad Awad Abdelrahman, Performance and exhaust emission characteristics of a diesel engine using alternative fuels, pp. 2140 - 2159

$$
\text { DBSFC }=\text { BSFC } \times \frac{\mathrm{LHV}_{\text {gas }} \times \mathrm{Z}+\mathrm{LHV}_{\text {Diesel }} \times(1-\mathrm{Z})}{\mathrm{LHV}_{\text {Diesel }}}
$$

The combustion duration is the time interval from the start of heat release to the end of heat release [20]. The author considered that the magnitude of errors in obtaining the experimental data were close to $10 \%$ in more cases. The total heat release rate was determined under dual fuel operation for each measured cylinder pressure point by applying the first law of thermodynamics using the following equation [8]:

$$
\frac{\mathrm{dQ}_{\text {total }}}{\mathrm{d} \theta}=\frac{\mathrm{dQ}_{1}}{\mathrm{~d} \theta}-\frac{\mathrm{dQ}_{2}}{\mathrm{~d} \theta}
$$

Where: the net heat release with crank angle $\left(\frac{\mathrm{dQ}_{1}}{\mathrm{~d} \theta}\right)$ is obtained from Eq.(4),

$$
\frac{\mathrm{dQ}_{1}}{\mathrm{~d} \theta}=\frac{C_{V}}{\mathrm{R}}\left(P \frac{\mathrm{dv}}{\mathrm{d} \theta}+\mathrm{V} \frac{\mathrm{dP}}{\mathrm{d} \theta}-\frac{P V}{\mathrm{~m}} \frac{\mathrm{dm}}{\mathrm{d} \theta}\right)+P \frac{\mathrm{dV}}{\mathrm{d} \theta}
$$

Eq.(5),using from) is obtained The heat loss rate with crank angle $\left(\frac{\mathrm{dQ}_{2}}{\mathrm{~d} \theta}\right.$ the well -tested heat transfer model [8]

$$
\frac{\mathrm{dQ}}{\mathrm{d} \theta}=\mathrm{A}\left(\mathrm{a}_{\mathrm{c}} \frac{\lambda}{\mathcal{D}} \mathcal{R} e^{\mathrm{b}}\left(\mathrm{T}_{\mathrm{w}}-\mathrm{T}_{\mathrm{g}}\right)+\varepsilon\left(\mathrm{T}_{\mathrm{w}}{ }^{4}-\mathrm{T}_{\mathrm{g}}{ }^{4}\right)\right)
$$

The constants $\left({ }^{a} \mathrm{c}=0.75 \& \mathrm{~b}=0.55\right)$, The mean gas temperature $\left(\mathrm{T}_{\mathrm{g}}\right)$ is calculated according to the measured cylinder pressure value and the measured total mass flow rate of the fuel with air mixture $\left(\mathrm{m}_{\mathrm{X}}\right)$ as follows,

$$
\begin{aligned}
& \mathrm{T}_{\mathrm{g}}=\frac{\mathrm{PV}}{\mathrm{m}_{\mathrm{x}} \mathrm{R}} \\
& \operatorname{Re}=\text { pair. } v \text { air dh / } \mu \text { air }
\end{aligned}
$$

\section{Result and Discussion}

In this section, the effects of the ratio of LPG or CNG in diesel fuel on the ignition delay, cylinder pressure, combustion duration, total brake specific fuel consumption and exhaust emissions are presented and discussed. Comparison between LPG-Diesel and CNG-Diesel dual fuel operation also is discussed.

\subsection{Comparison of the combustion characteristics}

The combustion characteristics of the engine when LPG-Diesel and CNG-Diesel dual fuels used are compared and displayed in Figs (2-9). Combustion characteristics are characterized by ignition delay, peak cylinder pressure, combustion duration, dual brake specific fuel consumption and heat release rate.

Journal of Engineering Sciences, Assiut University, Faculty of Engineering, Vol. 41, No. 6, November, 2013, E-mail address: jes@aun.edu.eg 
Saad Awad Abdelrahman, Performance and exhaust emission characteristics of a diesel engine using alternative fuels, pp. 2140 - 2159

\subsubsection{Ignition delay}

The ignition delay period is defined as the time interval from the start of liquid fuel injection to the start of combustion, [20]. The variation of ignition delay versus gaseous fuel mass ratios (LPG or CNG) for 25\% and $75 \%$ of full load at 1500 and $2500 \mathrm{rpm}$ respectively as rated working loads are shown in Fig. 2 and Fig. 3.

The results show that the ignition delay increases with the increase of the LPG mass ratio in the dual fuel. The increase could be explained by the decrease of cetane number with the increase of LPG mass ratio. Moreover, an increase in the heat of evaporation of the LPGDiesel dual fuel with the increase of the LPG mass ratio would decrease the temperature of the cylinder gases and this can also increase the ignition delay of the LPG-Diesel dual fuel. The ignition delay sharply increases at higher LPG mass ratio. Above 60\% of LPG mass ratio, the engine starts knocking and ignition fails. In this case, an additional amount of diesel fuel must be injected to ignite the gaseous-air mixture.

Also the figures show that the ignition delay increases with the increase of CNG mass ratio in the CNG-Diesel dual fuel. The increase is mainly due to the low temperature and airfuel ratio inside the combustion chamber, resulting in a slow combustion. The results show that the ignition delay under CNG-Diesel dual fuel is less than LPG-Diesel dual fuel. The dual fuel diesel engine could operate up to $100 \%$ of full load and up to $70 \%$ of CNG mass ratio without any problem.

\subsubsection{Peak cylinder pressure}

Variation of peak cylinder pressure versus gaseous mass ratio for $25 \%$ and $75 \%$ of full load at 1500 and 2500 rpm, respectively are shown in Fig. 4 and Fig.5.

The results show that the peak cylinder pressure first decreases with the increase of gaseous fuels (LPG) mass ratio up to $45 \%$ and then there's arise in the function. The behavior is more obvious at the high engine speed. This may be due to the comprehensive influence from the variation of the cetane number and the heat value of evaporation.

Also the results show that when burning CNG-Diesel duel fuel, the cylinder pressure strongly diverges from the respective values under normal diesel operation. Maximum combustion pressure is strongly affected by the presence of gaseous fuel. As the quantity of CNG mass ratio increases with keeping engine load constant, the peak cylinder pressure decreases significantly. The results show that the peak cylinder pressure under CNGDiesel dual fuel is lower than LPG-Diesel dual fuel.

\subsubsection{Combustion duration}

Combustion duration is defined as the crank angle difference between the start of combustion and the end of combustion. The combustion durations ate commonly used to describe the combustion characteristics. The combustion duration is the time interval from the start of heat release to the end of heat release.

Variation of combustion duration versus LPG mass ratio for $25 \%$ and $75 \%$ of full load at 1500 and 2500 rpm, respectively are shown in Fig.6 and Fig 7

Fig. 6 shows that the behavior of combustion duration versus LPG and CNG mass ratio. It can be classified into two cases, the first case is at low engine speed $(1500 \mathrm{rpm}, 25 \%$ of full load), where the total combustion duration decreases as LPG mass ratio increases (up to $40 \%$ ) and then increases as LPG mass ratio increases up to $60 \%$. Also the total Journal of Engineering Sciences, Assiut University, Faculty of Engineering, Vol. 41, No. 6, November, 2013, E-mail address: jes@aun.edu.eg 
Saad Awad Abdelrahman, Performance and exhaust emission characteristics of a diesel engine using alternative fuels, pp. 2140 - 2159

combustion duration decreases as CNG mass ratio increases (up to 70\%). While the second case is at high engine speed ( $2500 \mathrm{rpm} \& 25 \%$ of full load), the total combustion duration sharply increases at higher LPG and CNG mass ratio up to 70\%. LPG-Diesel dual fuel is better than CNG-diesel dual fuel. The engine produces highest combustion noise above $60 \%$ of LPG mass ratio.

Fig. 7 shows the variation of combustion duration versus CNG and LPG mass ratio at low engine speed (1500rpm \& $75 \%$ of full load). The results show that combustion duration under LPG/diesel dual fuel operation is decreases as mass ratio increases up to $45 \%$ and then the combustion duration increases as LPG mass ratio increases up to 60\%. Also, it is observed that a decrease of combustion duration with increasing $\mathrm{CNG}$ mass ratio up to $70 \%$ at the same above condition. But the other condition at high engine speed (2500rpm $\& 75 \%$ of full load), the results show that the combustion duration are increase as CNG and LPG mass ratio increase up to $70 \%$. CNG-Diesel dual fuel has low combustion duration compared to the case of LPG-Diesel dual fuel.

\subsubsection{Dual brake specific fuel consumption}

Fig. 8 shows the variation of the Dual brake specific fuel consumption (DBSFC) as a function of load at $2500 \mathrm{rpm}$ of engine speed at various LPG fuel mass ratios. The Dual brake specific fuel consumption is estimated from the brake power output of the engine and the equivalent mass flow rate of fuels. When the engine load is lower than $50 \%$ of full load, the dual brake specific fuel consumption slightly decreases with increase of the LPG mass ratios. When the engine load is higher than $50 \%$ of full load the dual brake specific consumption sharply increases at higher LPG mass ratios (above 60\%) to compensate the increase of engine loads.

Fig. 9 shows the variation of the dual brake specific fuel consumption (DBSFC) as a function of load at $2500 \mathrm{rpm}$ of engine speed at different $\mathrm{CNG}$ fuel mass ratios. At part load under dual fuel operation, the dual brake specific fuel consumption is considerably higher compared to the one under normal diesel engine, as a result of the low combustion rate of gaseous fuel. On the other hand, at high load, the improvement of gaseous load utilization leads to a relevant improvement of the dual brake specific fuel consumption of CNG-Diesel dual fuel, which tends to converge to the one under normal diesel fuel operation.

Results from Fig. 8 and Fig.9 show that the dual brake specific fuel consumption decreases under CNG-Diesel dual fuel smaller than the case of LPG-Diesel dual fuel and higher than the case of diesel fuel only.

\subsubsection{Heat release rate}

Results from Fig. 10 and Fig. 11 show that the heat release rate (kJ/ kW.h) of LPG-Diesel \&CNG-Diesel at $1500 \mathrm{rpm}, 2500 \mathrm{rpm}$ and 25\% load,75\%load are increase as the peak cylinder pressure (Mp) and the mass ratio increase. The heat release of LPG- Diesel is higher than that of CNG-Diesel. This increase is du to the increase of temperature difference between cylinder wall temperature (as peak cylinder pressure increase) and burned gas temperature. The heat release rates of LPG -Diesel and CNG-Diesel at 2500 $\mathrm{rpm} \& 25 \%$ load are higher than these at $1500 \mathrm{rpm} \& 25 \%$ load. Also the heat release rates of LPG -Diesel and CNG-Diesel at $2500 \mathrm{rpm} \& 75 \%$ load are higher than these at 1500

Journal of Engineering Sciences, Assiut University, Faculty of Engineering, Vol. 41, No. 6, November, 2013, E-mail address: jes@aun.edu.eg 
Saad Awad Abdelrahman, Performance and exhaust emission characteristics of a diesel engine using alternative fuels, pp. 2140 - 2159

rpm $\& 75 \%$ load. The combustion of gaseous fuel becomes deteriorating the heat release rate during the expansion stroke and the cylinder pressure as well.

\subsection{Comparison of exhaust emissions}

Fig. 12 to Fig. 17 compare the exhaust emissions characteristics of the engine when LPGdiesel and CNS-Diesel dual fuels are used respectively.

\subsubsection{Nitrogen oxides emissions}

Variations of $\mathrm{NO}_{\mathrm{x}}$ concentration at the engine exhaust under LPG-Diesel dual fuel operation are shown in Fig.12 at $2500 \mathrm{rpm}$ of engine speed.

The results showed that the concentration of $\mathrm{NO}_{\mathrm{x}}$ decreases with the increase of the LPG mass ratio in the dual fuel. The main reason is that an increase in the heat of evaporation of the LPG-Diesel dual fuel with the increase of the LPG mass ratio will decrease the temperature of the cylinder gases due to the fuel evaporation. Finally, the increase of engine speed under dual fuel operation results a further decrease of $\mathrm{NO}_{\mathrm{x}}$ values compared to diesel fuel operation. The concentration of $\mathrm{NO}_{\mathrm{x}}$ sharply increases at high LPG mass ratio (above $60 \%$ ).

Also the variations of $\mathrm{NO}_{\mathrm{x}}$ concentration at the engine exhaust under CNG-Diesel dual fuel operation is shown in Fig.13 at 2500 rpm engine speed. The increase of CNG mass ratio results a decrease of $\mathrm{NO}_{\mathrm{x}}$ concentration compared to the one under normal diesel operation. At high engine load and low mass ratios of CNG there is a sharp decreases of $\mathrm{NO}_{\mathrm{x}}$ concentration compared to the part load conditions, with the increasing gaseous fuel percentage.

Results indicate that the presence of $\mathrm{NO}_{\mathrm{x}}$ in the exhaust is low with LPG-Diesel or CNGDiesel dual fuel at all operating conditions. The results from Fig.12 and Fig.13 show that the $\mathrm{NO}_{\mathrm{x}}$ missions under CNG-Diesel dual fuel are lower than LPG-Diesel dual fuel.

\subsubsection{Hydrocarbon emissions}

Variations of HC, concentration as a function of engine load are shown in Fig. 14 and Fig.15 at $2500 \mathrm{rpm}$ of engine speed for both LPG-Diesel duel fuel and CNG-Diesel dual fuel operation, respectively. As observed, the variation of $\mathrm{HC}$ in the exhaust gases is consistent during the combustion process of the engine. Also, it is obvious that the HC emissions decrease with the increase of the LPG and CNG mass ratio at low engine loads and high engine load. The main reason is that the cylinder gas temperature is high for both LPG/Diesel and CNG/Diesel dual fuel operation at low and high engine load with the increase of $\mathrm{LPG}$ and $\mathrm{CNG}$ mass ratio.

The hydrocarbon decreases at higher LPG mass ratio (above 75\%). Under dual fuel operation, $\mathrm{HC}$ emission is generally lower than normal diesel operation.

\subsubsection{Carbon monoxide emissions}

Variations of $\mathrm{CO}$ concentration as a function of engine load are shown in Fig.16 and Fig.17 at $2500 \mathrm{rpm}$ of engine speed for both LPG-Diesel duel fuel and CNG-Diesel dual fuel operation, respectively. Results of CO emissions under LPG-Diesel dual fuel are shown in Fig. 14 at $2500 \mathrm{rpm}$ as a function of engine load. The rate of $\mathrm{CO}$ formation is a function of unburned gaseous fuel availability and mixture temperature. Both the rate of

Journal of Engineering Sciences, Assiut University, Faculty of Engineering, Vol. 41, No. 6, November, 2013, E-mail address: jes@aun.edu.eg 
Saad Awad Abdelrahman, Performance and exhaust emission characteristics of a diesel engine using alternative fuels, pp. $2140-2159$

fuel decomposition and oxidation are controlled. It is obvious that the $\mathrm{CO}$ emissions are slightly increasing at low engine load. But at high load, CO emissions are evidently increased with the increase of the LPG mass ratio.

The results of $\mathrm{CO}$ emissions under CNG-Diesel dual fuel at $2500 \mathrm{rpm}$ as a function of engine load is shown in Fig.15. At high engine load, $\mathrm{CO}$ emissions decreases with the increase of $\mathrm{CNG}$ mass ratio and beyond a certain value of gaseous fuel mass ratio they start to decreases, as a result of both high gas temperature and fast combustion rate.

In general CO emissions values under CNG-Diesel dual fuel are lower than normal Diesel fuel operation. The best combustion performance and the lowest relative emissions of carbon are in CNG-Diesel dual fuel compared to normal Diesel operation and LPG dual fuel.

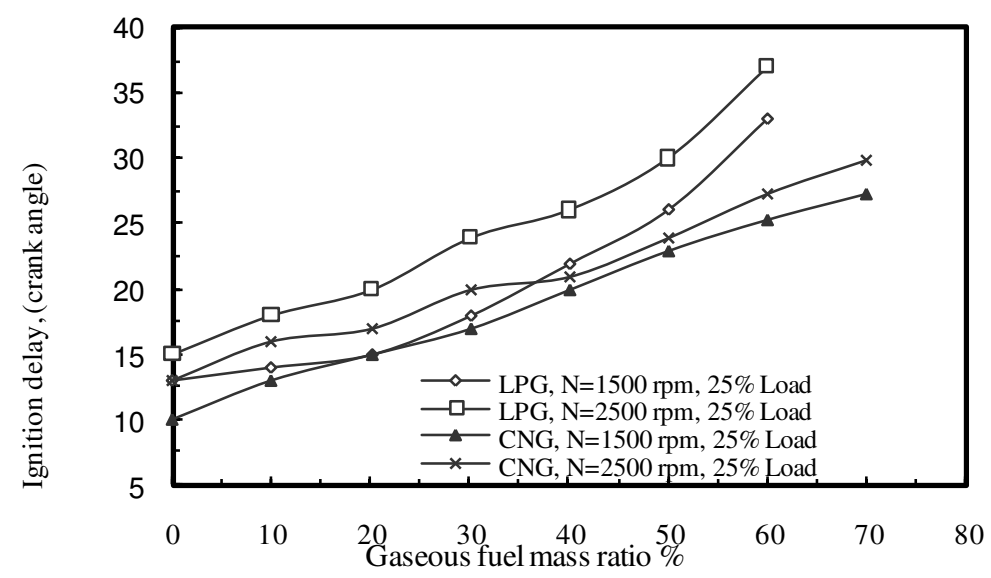

Fig. 2. Variation of ignition delay as function of gaseous fuel ratio at 1500 and $2500 \mathrm{rpm}$ for $25 \%$ load ( Comparison between LPG and CNG)

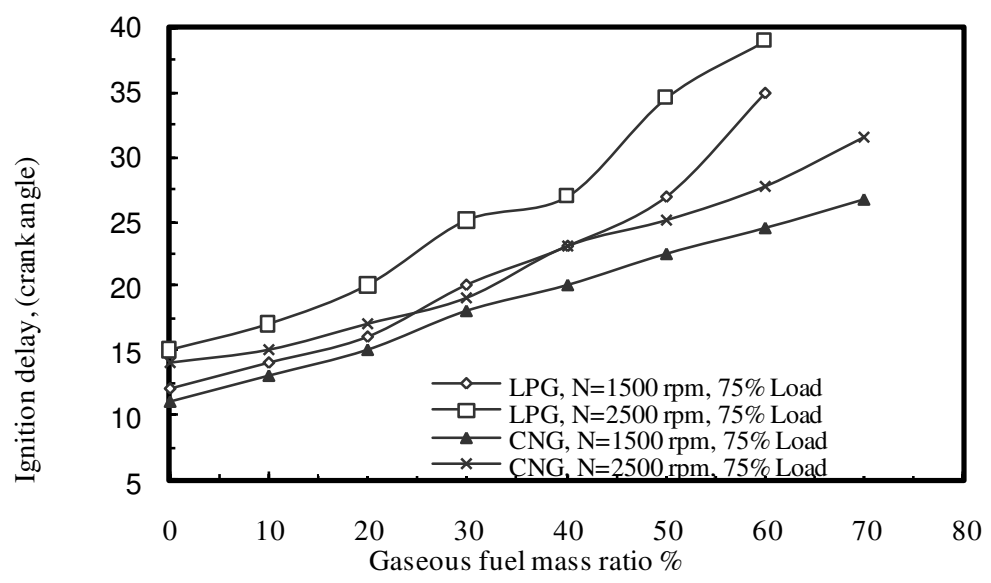

Fig. 3. Variation of ignition delay as function of gaseous fuel ratio at 1500 and $2500 \mathrm{rpm}$ for $75 \%$ load ( Comparison between LPG and CNG)

Journal of Engineering Sciences, Assiut University, Faculty of Engineering, Vol. 41, No. 6, November, 2013, E-mail address: jes@aun.edu.eg 
Saad Awad Abdelrahman, Performance and exhaust emission characteristics of a diesel engine using alternative fuels, pp. 2140 - 2159

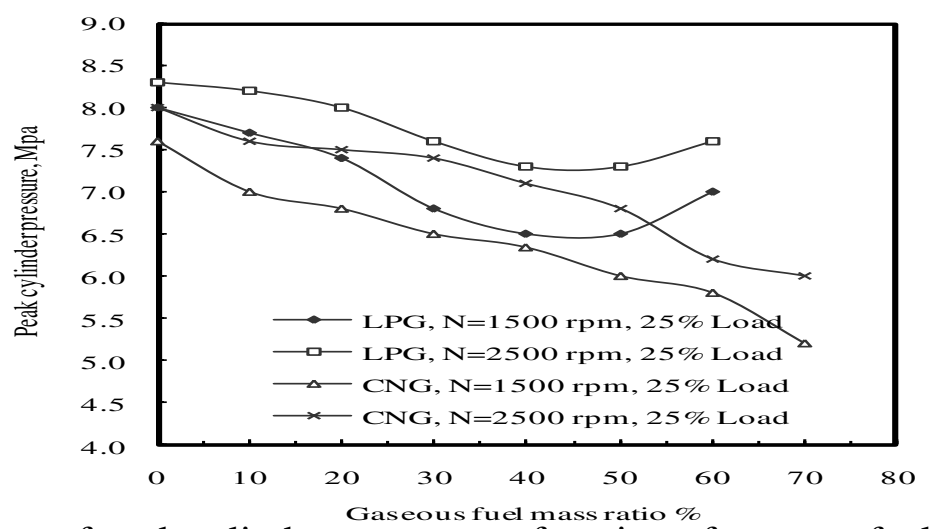

Fig. 4. Variation of peak cylinder pressure as function of gaseous fuel mass ratio at 1500 and $2500 \mathrm{rpm}$ for 25\% load (Comparison between LPG and CNG)

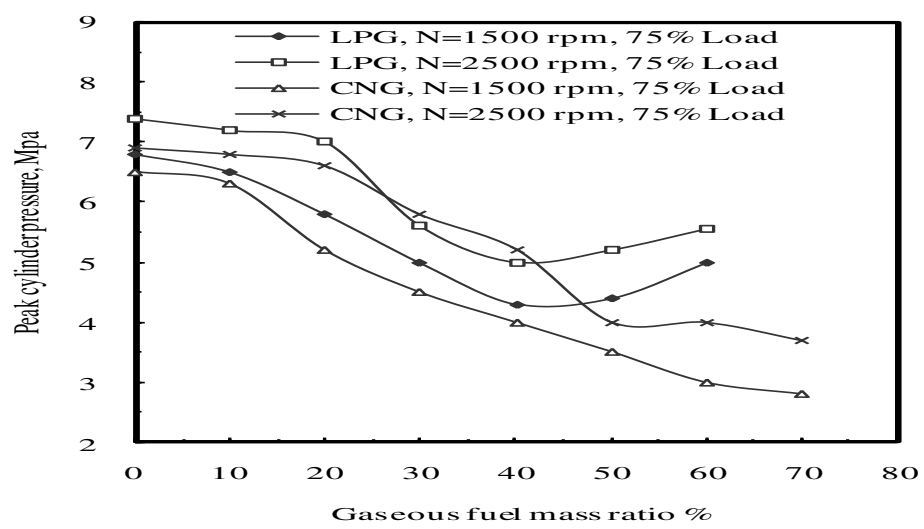

Fig. 5. Variation of peak cylinder pressure as function of gaseous fuel mass ratio at 1500 and $2500 \mathrm{rpm}$ for $75 \%$ load (Comparison between LPG and CNG)

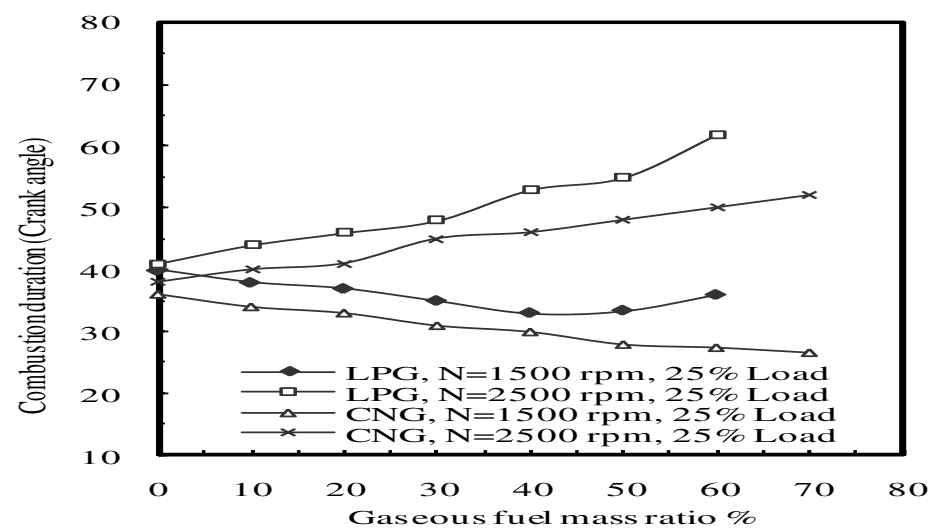

Fig. 6. Variation of combustion duration as function of gaseous fuel mass ratio at 1500 and $2500 \mathrm{rpm}$ for $25 \%$ load (Comparison between LPG and CNG)

Journal of Engineering Sciences, Assiut University, Faculty of Engineering, Vol. 41, No. 6, November, 2013, E-mail address: jes@aun.edu.eg 
Saad Awad Abdelrahman, Performance and exhaust emission characteristics of a diesel engine using alternative fuels, pp. 2140 - 2159

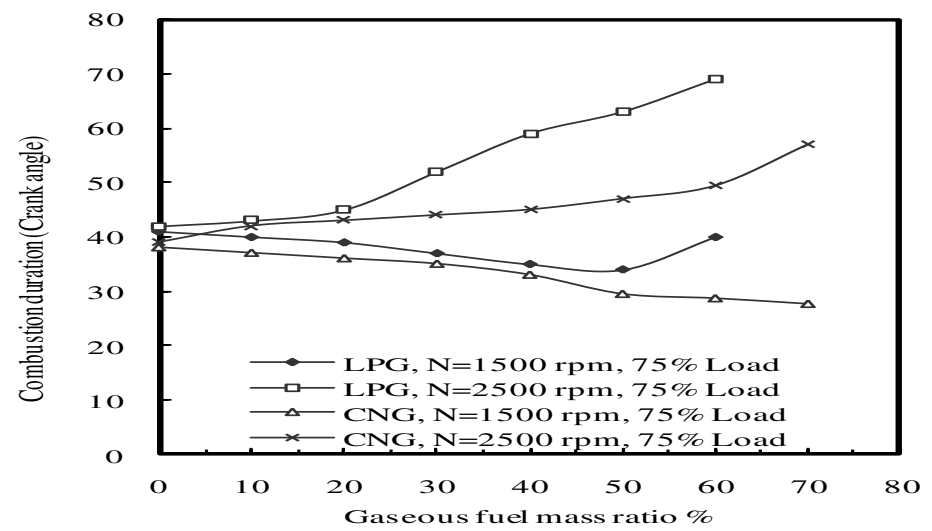

Fig. 7 . Variation of combustion duration as function of gaseous fuel mass ratio at 1500 and $2500 \mathrm{rpm}$ for $75 \%$ load (Comparison between LPG and CNG)

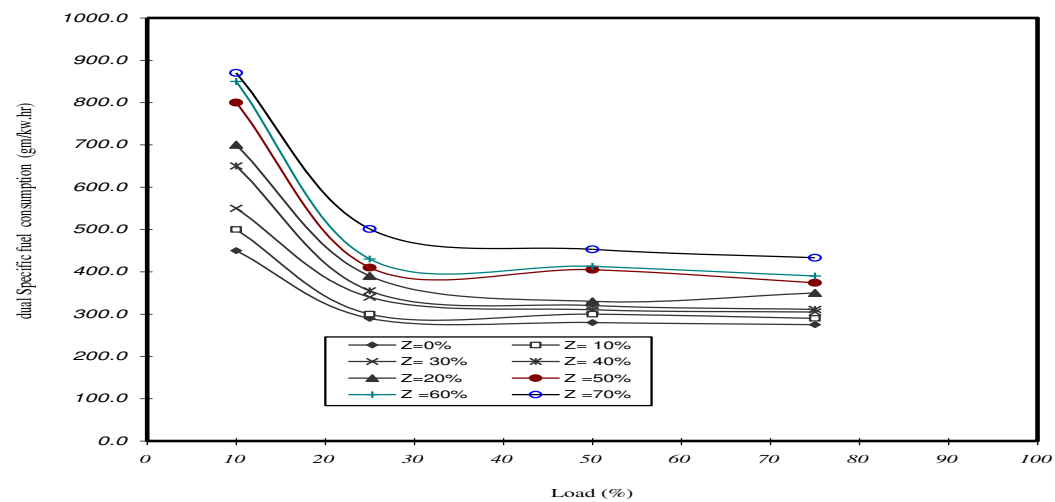

Fig. 8. Variation of dual brake specific fuel consumption as function of load at $2500 \mathrm{rpm}$ for different LPG fuel mass ratios

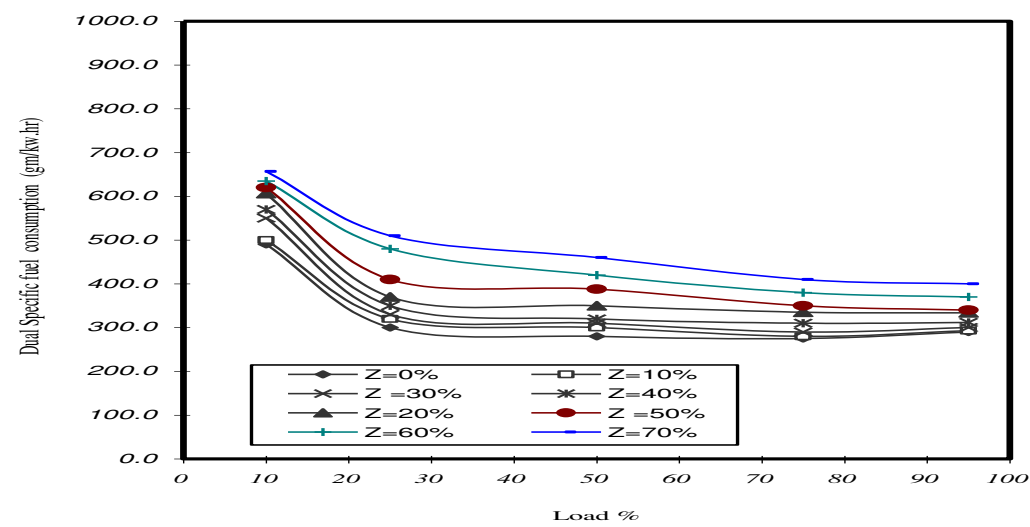

Fig. 9. Variation of dual brake specific fuel consumption as function of load at $2500 \mathrm{rpm}$ for different $\mathrm{CNG}$ fuel mass ratios

Journal of Engineering Sciences, Assiut University, Faculty of Engineering, Vol. 41, No. 6, November, 2013, E-mail address: jes@aun.edu.eg 
Saad Awad Abdelrahman, Performance and exhaust emission characteristics of a diesel engine using alternative fuels, pp. $2140-2159$

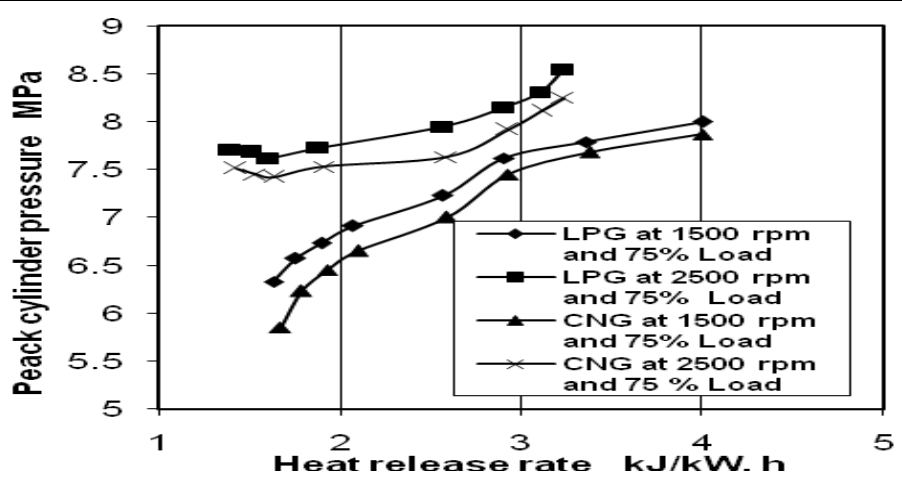

Fig. 10 . Variation of peak cylinder pressure (P.C.P) for different LPG \& CNG mass ratio versus Heat release rate (H.R.R) at $1500 \mathrm{rpm} \& 2500 \mathrm{rpm}$ and $75 \%$ load

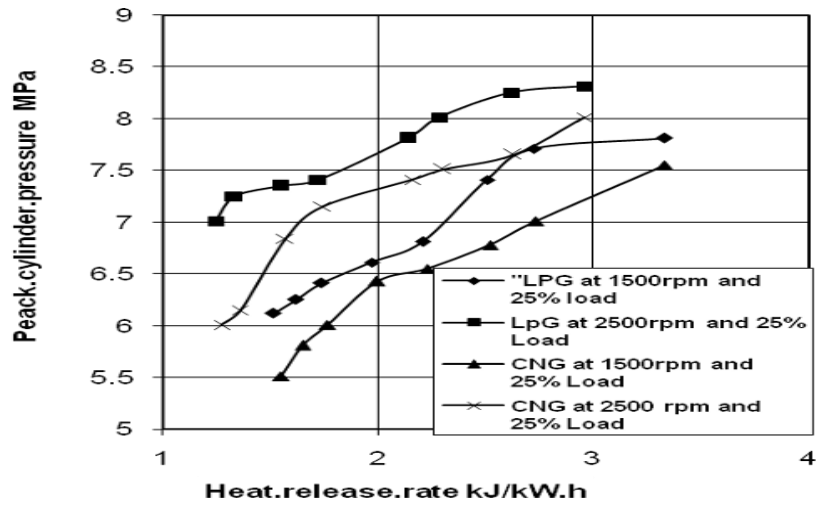

Fig. 11 . Variation of peak cylinder pressure (P.C.P) for different LPG \& CNG mass ratio versus Heat release rate (H.R.R) at $1500 \mathrm{rpm} \& 2500 \mathrm{rpm}$ and $25 \%$ load

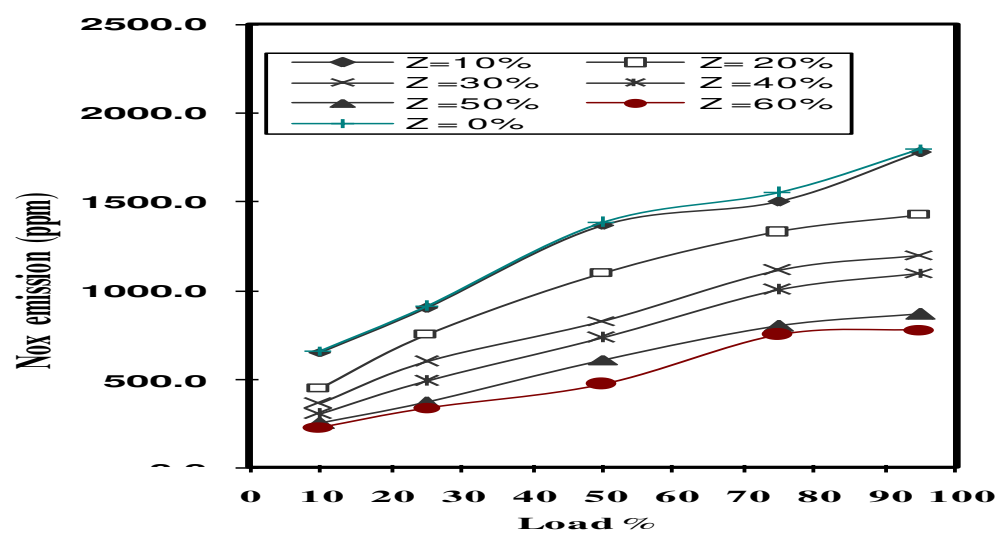

Fig. 12. Variation of nitrogen oxide as function of load at $2500 \mathrm{rpm}$ for different LPG mass ratios

Journal of Engineering Sciences, Assiut University, Faculty of Engineering, Vol. 41, No. 6, November, 2013, E-mail address: jes@aun.edu.eg 
Saad Awad Abdelrahman, Performance and exhaust emission characteristics of a diesel engine using alternative fuels, pp. 2140 - 2159

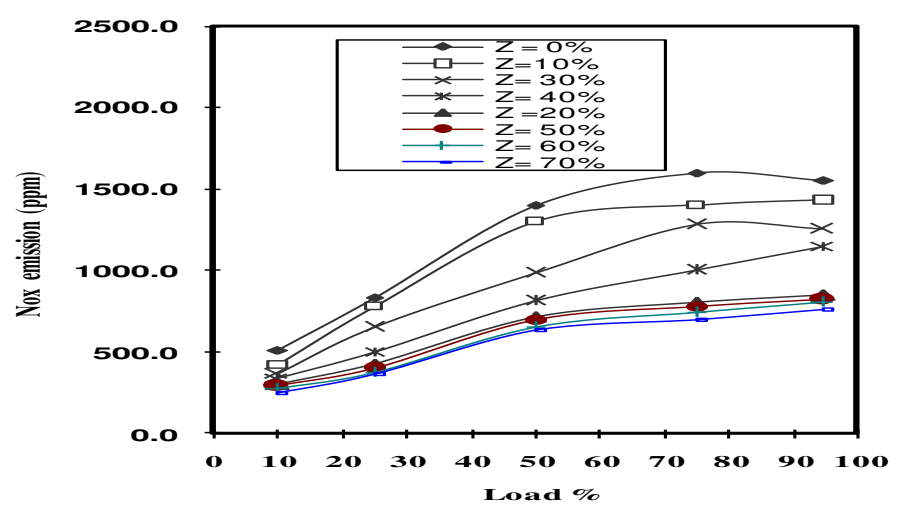

Fig. 13. Variation of nitrogen oxide as function of load at $2500 \mathrm{rpm}$ for different CNG mass ratios

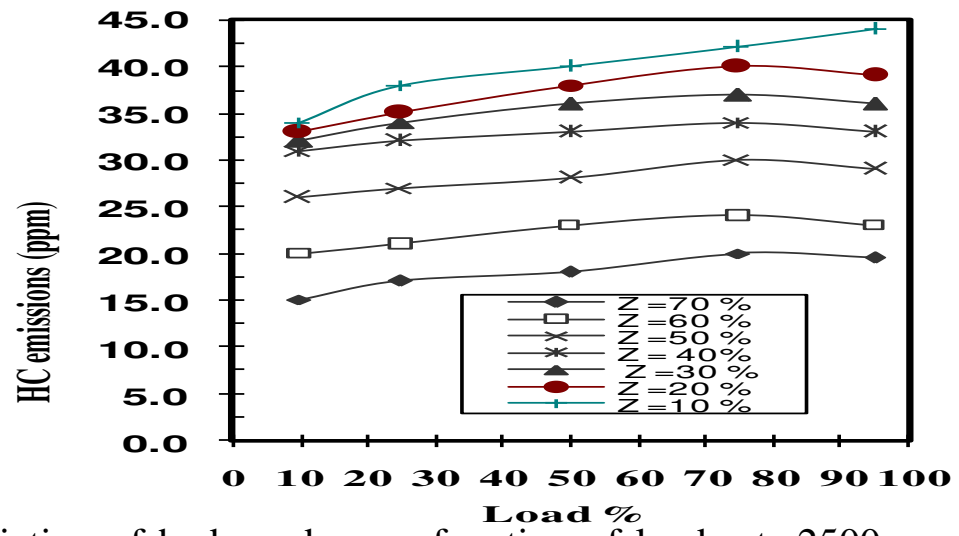

Fig. 14. Variation of hydrocarbon as function of load at $2500 \mathrm{rpm}$ for different LPG mass ratios

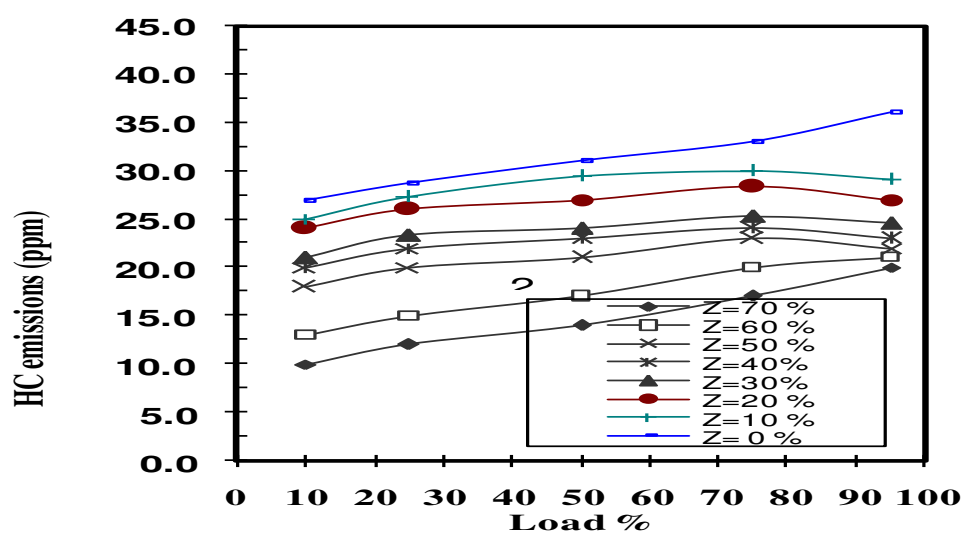

Fig. 15. Variation of hydrocarbon as function of load at $2500 \mathrm{rpm}$ for different CNG mass ratios

Journal of Engineering Sciences, Assiut University, Faculty of Engineering, Vol. 41, No. 6, November, 2013, E-mail address: jes@aun.edu.eg 
Saad Awad Abdelrahman, Performance and exhaust emission characteristics of a diesel engine using alternative fuels, pp. 2140 - 2159

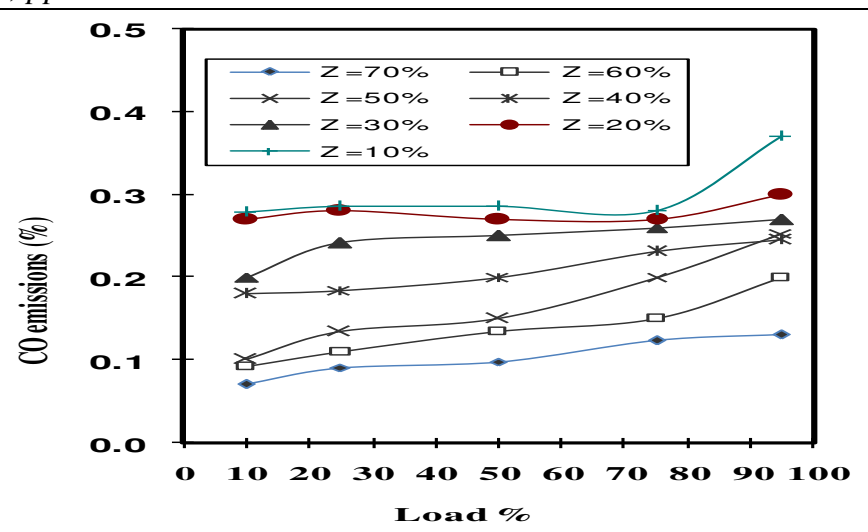

Fig.16. Variation of carbon monoxide as function of load at $2500 \mathrm{rpm}$ for different LPG mass ratios

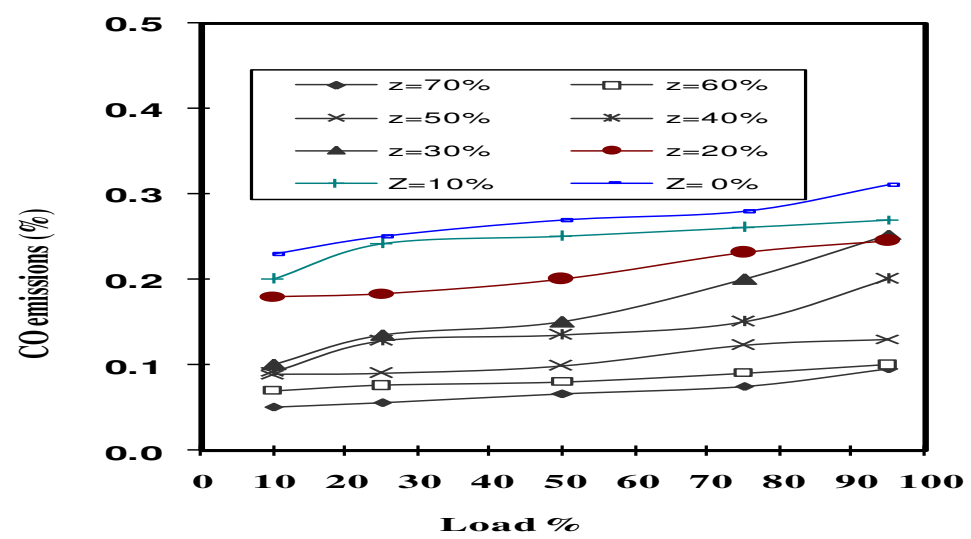

Fig.17. Variation of carbon monoxide as function of load at 2500rpm for different CNG mass ratios

\section{Nomenclature}

\begin{tabular}{|c|c|c|c|c|c|}
\hline Symbol & Description & units & Symbol & Description & $\underline{\text { Units }}$ \\
\hline $\overrightarrow{\mathrm{A}}$ & $\overline{\text { Cylinder area }}$ & $\mathrm{m}^{2}$ & $\mathrm{R}$ & Specific gas constant & $\overline{\mathrm{J} / \mathrm{kg} \cdot \mathrm{K}}$ \\
\hline b.m.e.p & Brake mean effective pressure & $\mathrm{MPa}$ & $\operatorname{Re}$ & Reynolds number & \\
\hline BSFC & Brake specific fuel consumption & g/kW.h & $\mathrm{T}$ & Temperature & K \\
\hline $\mathrm{C}_{\mathrm{P}}$ & Constant pressure specific heat & $\mathrm{kJ} / \mathrm{kg} . \mathrm{K}$ & DBSFC & C Dual brake specific & \\
\hline $\mathrm{C}_{\mathrm{V}}$ & Constant volume specific heat & $\mathrm{kJ} / \mathrm{kg} . \mathrm{K}$ & & fuel consumption & g/kW.h \\
\hline $\mathrm{D}, \mathrm{d}$ & Cylinder bore, air intake diameter & $\mathrm{r} \mathrm{m}$ & V & Volume & $\mathrm{m}^{3}$ \\
\hline LHV & Lower heating value & $\mathrm{kJ} / \mathrm{kg}$ & $\mathrm{z}$ & \multicolumn{2}{|c|}{ mass ratio of $\mathrm{LPG}$ or $\mathrm{CNG}$} \\
\hline $\mathrm{m}$ & Mass & $\mathrm{kg}$ & C & Crank angle & eg.CA \\
\hline $\mathrm{m}$ & Mass flow rate & $\mathrm{kg} / \mathrm{h}$ & $\epsilon$ & \multicolumn{2}{|l|}{ Stefan-Boltzmann } \\
\hline $\mathrm{N}$ & Engine speed & r.p.m & & constant & $\mathrm{J} / \mathrm{m}^{2} \mathrm{~K}^{4}$ \\
\hline $\mathrm{P}$ & Cylinder pressure & $\mathrm{Mpa}$ & $\lambda$ & \multicolumn{2}{|c|}{ Cylinder thermal conductivity } \\
\hline$P$ & Brake power & $\mathrm{kW}$ & & conductivity & $\mathrm{W} / \mathrm{m} \mathrm{K}$ \\
\hline Q & Heat transfer rate & $\mathrm{J} / \mathrm{s}$ & $\begin{array}{l}\dot{\rho} \\
v\end{array}$ & $\begin{array}{l}\text { Air density } \\
\text { Air velocity }\end{array}$ & $\begin{array}{l}\mathrm{kg} / \mathrm{m}^{3} \\
\mathrm{~m} / \mathrm{s} .\end{array}$ \\
\hline
\end{tabular}

Journal of Engineering Sciences, Assiut University, Faculty of Engineering, Vol. 41, No. 6, November, 2013, E-mail address: jes@aun.edu.eg 
Saad Awad Abdelrahman, Performance and exhaust emission characteristics of a diesel engine using alternative fuels, pp. $2140-2159$

$\begin{array}{llll}\text { A/D } & \text { Analog/Digital } & \text { v1,v2,v3,v4 } & \text { Control valves } \\ \mathrm{CO} & \text { Carbon monoxide, } \% & & \\ \mathrm{CNG} & \text { Compressed natural gas } & \mathrm{GFM} & \text { Gaseous fuel mixer } \\ \mathrm{HC} & \text { Hydrocarbons, ppm } & \mathrm{ppm} & \text { Parts per million (Volume) } \\ \mathrm{LPG} & \text { Liquefied petroleum gas } & & \\ \mathrm{OHV} & \text { Over head valve } & & \\ \mathrm{NO}_{\mathrm{x}} & \text { Nitrogen oxides, ppm } & & \end{array}$

\section{Subscripts}

$\begin{array}{cl}\mathrm{g} & \text { Gas } \\ \mathrm{w} & \text { Cylinder wall } \\ \mathrm{ac} & \text { Constant } \\ \mathrm{h} & \text { Hose }\end{array}$

\section{Conclusions}

In the present work, an experimental investigation has been conducted to test the effect of combustion of both LPG-diesel and CNG-Diesel dual fuel on performance and exhaust emissions of a single cylinder Diesel engine respectively. The Diesel engine has been properly modified to operate under both LPG fuel and CNG fuel. The major conclusions from the present study are as follows:

1-The ignition delay increases with the increase of gaseous fuel (LPG or CNG) ratios in Diesel fuel compared to normal Diesel fuel operation. The ignition delay with CNG- Diesel dual fuel operation is lower than that of LPG-diesel dual fuel.

2- The use of gaseous fuel leads to decrease the peak cylinder pressure compared to normal Diesel fuel operation. The combustion duration in most cases is increased with the increasing of gaseous fuel mass ratio. The combustion duration with CNG -Diesel fuel is lower than that when using of LPG-Diesel dual fuel at the same operating conditions.

3-The dual brake specific fuel consumption is increased under dual fuel operations compared to the one under normal Diesel operation at low engine load. At high load, the values of dual brake specific fuel consumption under dual fuel operations tend to converge to the ones under normal Diesel fuel operation at the same conditions.

4- The use of gaseous fuel has a positive effect on NOx emissions. The level of NOx concentration under dual fuel operation is lower compared to normal Diesel fuel operation. The level of NOx with CNG-Diesel fuel is higher than with LPGDiesel dual fuel. $\mathrm{CO}$ and $\mathrm{HC}$ emissions are generally lower than normal diesel fuel operation.

5- By using CNG-Diesel dual fuel, the engine can operate up to $100 \%$ of full load and up $70 \%$ of CNG mass ratio without any problems .

Journal of Engineering Sciences, Assiut University, Faculty of Engineering, Vol. 41, No. 6, November, 2013, E-mail address: jes@aun.edu.eg 
Saad Awad Abdelrahman, Performance and exhaust emission characteristics of a diesel engine using alternative fuels, pp. 2140 - 2159

6- The final results show that the higher combustion performance and the lowest relative exhaust emissions are when using CNG compared to diesel and LPG dual fuel at the same operating conditions.

\section{References}

[1] Thring, R.H. (1983), Alternative Fuels for Spark-Ignition Engines. SAE, Paper no. 831685 , pp. 4715-4725.

[2]Beer T,Grant B,Williams D,Watson H. (2000), Fuel-cycle greenhouse gas emissions from alternative fuels in Australian heavy vehicles .Atmos Environ;36,pp.753 -763.

[3] Bayraktar H,Durgun O.(1988), The effects of using gaseous fuels on engine combustion and performance. The sixth combustion symposium. Istanbul,Turkey,p.273 -285.

[4] Poulton, ML. (1994), Alternative fuels for road vehicles. Bellerica, MA: Computational Mechanics Publications.

[5]Hountalas DT, Papagiannakis RG.(2000), Development of a simulation model for direct injection dual fuel Diesel-natural gas engines. SAE Trans 2000-01-0286.

[6]Daisho Y,Yaeo T,Koseki T,Saito T,Kihara R,Quiros EN.(1995), Combustion and exhaust emissions in a direct injection Diesel engine dual-fuelled with natural gas. SAE Paper No.950465.

[7] Poonia MP, Ramesh A, Gaur RR. (1999), Experimental investigation of the factors affecting the performance of a LPG-Diesel dual fuel engine. SAE 1999-01-1123, 1999.

[8]Papagiannakis RG,Hountalas DT.(2003, Experimental investigation concerning the effect of natural gas percentage on performance and emissions of a DI dual fuel Diesel engine.Int $\mathbf{J}$ Appl Therm Eng;23,pp353 -365.

[9]Cao J,Bian Y,Qi D,Cheng Q,Wu T.(2004), Comparative investigation of Diesel and mixed liquefied petroleum gas/Diesel injection engines. Proc IMechE Part D:J Automobile Eng;218, pp557 -565.

[10] Homeyer C, Choi GH, Kim JH.(2002), Effects of different LPG fuel systems on performances of variable compression ratio single cylinder engine. ASME Internal Combustion Engine Division; 39, pp369 -375.

[11]Selim MYE.(2004), Sensitivity of dual fuel engine combustion and knocking limits to gaseous fuel composition.Energ Convers Manage;45, pp411 -425.

[12]Lutz,Barry R,Stanglmaier, Rudolf H,Matthews, Ronald D, et al.(1998), The effects of fuel composition, system design, and operating condition on in-system vaporization and hot start of a liquid-phase LPG injection system. SAE paper 981388.

[13] Snelgrove DG, Dupont P, Bonetto R.(1996), An investigation into the influence of LPG (auto-gas) composition on the exhaust emissions and fuel consumption of 3bi-fuelled Renullt vehicles. SAE 961170.

[14] Nicolas B.C. Ahouissoussi, Michael E. Wetzstein.(1997), A comparative cost analysis of biodiesel, compressed natural gas, methanol, and Diesel for transit bus system Resource and Energy Economics 20, pp. 1-5.

[15]Nwafar OMI,Rice G. Combustion characteristics and performance of natural gas in high speed indirect injection diesel engine. Renew Energy 1994;5(Part II):pp841 -848.

[16]Nwafor OMI,Rice G.(1994), Combustion characteristics and performance of natural gas in high speed, indirect injection Diesel engine.UK:WREC;.pp841.

[17]Naber JD, Siebers DL, Julio D, Westbrook CK.(1994), Effects of natural gas composition on ignition delay under diesel conditions. Combust Flame; 99(2), pp192 -200.

[18] Karim GA, Liu Z.(1995), The ignition delay period of dual fuel engines. SAE 950466.

Journal of Engineering Sciences, Assiut University, Faculty of Engineering, Vol. 41, No. 6, November, 2013,E-mail address: jes@aun.edu.eg 
Saad Awad Abdelrahman, Performance and exhaust emission characteristics of a diesel engine using alternative fuels, pp. 2140 - 2159

[19]Mtui PL, Hill PG.(1996), Ignition delay and combustion duration with natural gas fueling of Diesel engines. SAE paper 961933.

[20] Qi Donghui,Zhou Longbao,Liu Shenghua.(2006), Experimental studies on the combustion characteristics and performances of a naturally aspirated, DI Diesel engine fueled with LPG/Diesel blend.Proc IMechE Part D:J Automobile Eng;219, pp253 -261.

[21] D.H.Qi, Y.Z. Bian, ZH.Y. Ma, CH.H.Zhange, SH.Q. Lui. (2006), Combustion and exhaust emission characteristics of a compression ignition engine using petroleum gas-Diesel blended fuel. Energy Conversion and Management 48, 500-509.

[22] J.B.Heywood,(1988),Internal Combustion Engine Fundamentals., McGraw-Hill Book Co., New York.

[23] Elnajjar Emad, Selim Mohamed YE, Omar Farag (2011)," Pressure-comparison study of dual fuel engine performance and overall generated noise under different dual fuel types and engine parameters. IJBAS-IJENS:2011(03).

[24] V Aylan, A. Parlak, J.Cesur, B.Boru and A.Kolip (2011), "Performance and exhaust emission characteristics of a diesel engine running with LPG ", International Journal of the Physical sciences vol.6. no.8 pp.1905-1914 April 2011.

[25] J. P. Holman, "Experimental Methods for Engineers" McGraw-Hill International Edition, Seven Edition, New York, 2001.

[26] G.A. Karim, (1988), A review of combustion processes in the dual fuel engine-the diesel engine .Proc. Energy Combustion Science 6, pp.277-285.

\section{Appendix (A) $[8,15,26]$}

\begin{tabular}{|c|c|c|c|}
\hline Property & Diesel & LPG & CNG \\
\hline Composition & $\mathrm{C}_{12} \mathrm{H}_{26}$ & $\begin{array}{l}70 \% \text { Propane }\left(\mathrm{C}_{3} \mathrm{H}_{8}\right) \\
+30 \% \text { Butane }\left(\mathrm{C}_{4} \mathrm{H}_{10}\right)\end{array}$ & $\begin{array}{l}93.80 \% \text { methane }\left(\mathrm{CH}_{4}\right) \text {, } \\
3.28 \% \text { ethane }\left(\mathrm{C}_{2} \mathrm{H}_{6}\right) \text {, } \\
0.15 \% \text { nitrogen }\left(\mathrm{N}_{2}\right) \text {, } \\
0.53 \% \text { carbon dioxide } \\
\left(\mathrm{CO}_{2}\right), 1.20 \% \text { propane } \\
\left(\mathrm{C}_{3} \mathrm{H}_{8}\right), 1 \% \text { the remains } \\
\text { (butane, pentane , } \\
\text { hexanes, water). }\end{array}$ \\
\hline $\begin{array}{l}\text { Relative density, } \\
\mathrm{kg} / \mathrm{m}^{3}\end{array}$ & 815 & 2.15 & 0.83 \\
\hline Octane number & - & $100-110$ & $120-130$ \\
\hline Cetane number & 45 & - & - \\
\hline $\begin{array}{l}\text { Lower heating value } \\
(\mathrm{LHV}),(\mathrm{kJ} / \mathrm{kg})\end{array}$ & 42500 & 46300 & 47700 \\
\hline
\end{tabular}

Journal of Engineering Sciences, Assiut University, Faculty of Engineering, Vol. 41, No. 6, November, 2013,E-mail address: jes@aun.edu.eg 
Saad Awad Abdelrahman, Performance and exhaust emission characteristics of a diesel engine using alternative fuels, pp. 2140 - 2159

تحليل أداء وانبعاث غازات العادم لمحركات الديزل بإستخدام الوقود البديل

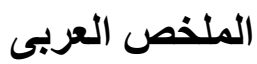

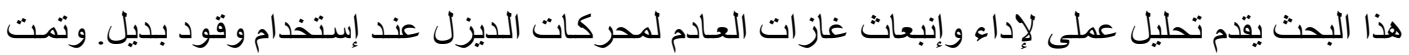

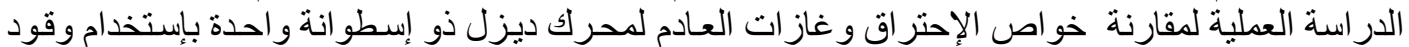

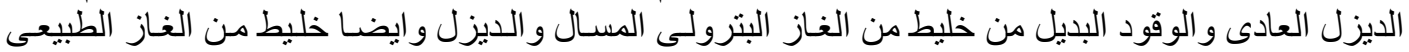

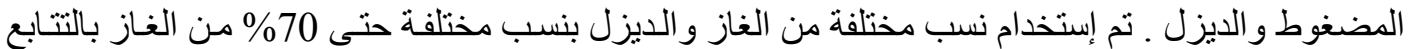
وتم إنشاء وحدة معملية متصلة بحاسب آلى ودائرة تحكم و إدخال البيانات وكارت تحصيل البيانات و إجهزة القياس المختلفة أنماء.

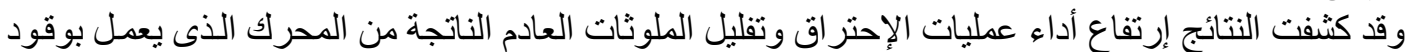

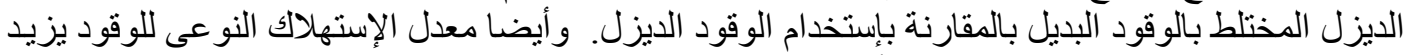
يزيادة نسبة الخلط بالوقود الغازى البذ عند الأحمال المختلفة. 